MATEC Web of Conferences 47, 01017 (2016)

DOI: $10.1051 /$ matecconf/20164701017

(C) Owned by the authors, published by EDP Sciences, 2016

\title{
A Review on Interlocking Compressed Earth Blocks (ICEB) with Addition of Bacteria
}

\author{
J. M. Irwan ${ }^{1, a}$, M. M. Zamer ${ }^{1}$ and N. Othman ${ }^{1}$ \\ ${ }^{1}$ Faculty of Civil and Environmental Engineering, Universiti Tun Hussein Onn Malaysia, 86400 Parit Raja, Johor, \\ Malaysia
}

\begin{abstract}
Interlocking Compressed Earth Block (ICEB) are cement stabilized soil blocks that allow for dry stacked construction. Because of this characteristic, the process of building walls is faster and requires less skilled labour as the blocks are laid dry and lock into place. However there are plenty room for improving the interlocking blocks by increase its durability. Durability of bricks are affected by several factors and one of them are water absorption. High water absorption level will results in low durability. Many studies have been conducted in order to improve the durability of bricks by using environmentally method. One of the method is by inducing bacteria into bricks. Bacteria in brick induced calcite precipitation (calcite crystals) to cover the cracks continuously. Therefore, the issues of durability of bricks can be fully solved. This paper offer a review on interlocking compressed earth blocks and the use of bacteria in reducing water absorption level.
\end{abstract}

\section{Introduction}

Interlocking compressed earth block (ICEB) is a cost effective and sustainable construction material which has potential to bring durable and affortable homes to developing counties around the world [1]. ICEB is an earthen bricks compressed with hand-operated or motorized hydraulic machines.

Interlocking Compressed Earth Block (ICEB) are energy efficient because its require anywhere from $1 / 5$ to $1 / 15$ of the energy to make when compared to fired bricks and concrete masonry units [2]. According to Maini [2] there is a large reduction in purchased material since soil is the main ingredient in ICEBs construction. As we know the traditional masonry relies heavily on skilled labor, expensive materials and time consuming. The interlocking nature of ICEBs allows for dry stacked, mortar-less construction, which reduces the need for skilled labor and shortens construction time. These reductions lower the cost of labor by as much as $80 \%$ [3]. These advantages make ICEBs a practical and preferred construction form.

However there are problems associated with bricks which are low strength, higher water absorption, low fire resistance and high porosity. Water absorption is a function of clay and cement content and usually related with the strength and durability of earth bricks [4]. Higher rate of water absorption will results in low compressive strength and durability. Numbers and size of pore in brick also affected the rate of water absorption. The bigger size of pore, the faster the brick will absorb

\footnotetext{
${ }^{a}$ Corresponding author : irwan@uthm.edu.my
} 
water. Therefore this paper will provide an overview on the problem solving method that had been done by previous researcher by introducing the used of bacteria in brick or concrete.

\section{Water Absorption and Moisture Content}

There is a small but set volume of water present in the form of liquid bridges between soil particles in earth structures when air dried [5]. According to Jaquin [5], "This water is under tension and the magnitude of the pore water pressure (suction) is related to the relative humidity of the surrounding air". It has been identified by [6] that the evaporation of water from unsaturated soils is proportional to the suction. However [7] argued that this evaporation will continue from the earth structure until the relative humidity of the pore air is equal to the humidity of the surrounding air. According to [5], the strength and stiffness of earth structures, and therefore their inherent viability is a function of the mean relative humidity of a region.

Water absorption is a characteristic of clay and cement content and is often related to the strength and durability of earth blocks, therefore it is important to identify the rate of water absorption of earth blocks [4]. According to Oti et al. [8], water absorption rate decreases with increasing age of earth blocks. High rate of water absorption of a specimen may cause swelling of the stabilized clay fraction which will result in losing strength with time [4]. Walker [9] observed that water absorption and porosity increases with clay content and decreasing with cement content. Between cement, lime, cement-lime and cement-resin, combination cement showed the lowest absorption both in capillary absorption and total absorption [10].

Moisture content affects strength development and durability of earth blocks having a significant influence on the long term performance and the effectiveness of the bonding with the mortar at the time of construction [4]. Once the earth block is dry, water is rapidly drawn out of the mortar preventing good adhesion and proper hydration of cement [8]. Due to this Adam et al [11] stated that to achieve maximum strength, compressed earth block need a period of damp curing, where they are kept moist, to prevent rapid moisture evaporation.

\section{Compressed Earth Blocks Failure due to Moisture}

Moisture related deterioration in compressed earth blocks is due to seasonal or continuous alternate wetting (rainfall) and drying which lead to the block retaining sufficiently high amounts of moisture which leads to destructive effects. The softening and abrasive action of moisture leads to erosion of exposed surfaces [12].

Keefe [13] stated that over the years a building constructed of compressed earth blocks exposed to the elements will be affected by rainwater and due to the ageing of these blocks surface cracks will appear. This will result in water penetration and a build-up of moisture to a critical level [13]. According to Keefe [13] "compressive strength decreases with increasing moisture content and once it reaches its critical moisture content it is likely to fail". Minimal moisture content will results in better strength, water resistance and durability of the blocks.

Actual destructive action of moisture once the block has been penetrated is the dissolution and softening of loose particles and the pore pressure generated will result in a disruptive internal stress. Therefore the capacity of the block to resist the disruptive action of moisture will differentiate the life span of the earth block.

\section{Bacteria}

Siddique and Chahal [14] has define bacteria as unicellular (single cell) micro-organisms. Bacteria from various natural habitats have frequently been reported to precipitate calcium carbonate both in natural and in laboratory conditions [15]. Different types of bacteria, as well as abiotic factors (salinity and composition of the medium) seem to contribute in a variety of ways to calcium carbonate 
precipitation in a wide range of environments [16]. Bacillus species are able to precipitate calcium carbonate $\left(\mathrm{CaCO}_{3}\right)$ on its cell constituents and in its micro-environment by decomposition of urea $\left(\mathrm{CO}\left(\mathrm{NH}_{2}\right)_{2}\right)$ into ammonium $\left(\mathrm{NH}_{4}{ }^{+}\right)$and carbonate $\left(\mathrm{CO}_{3}{ }^{2-}\right)$ [17]. The bacterial degradation of urea locally increases the $\mathrm{pH}$ and promotes the microbial deposition of calcium carbonate in a calcium rich environment. In the presence of dissolved calcium ions, the produced carbonate ions precipitate and form calcium carbonate crystals [18]. Microbial mineral precipitation technologies have been successfully demonstrated for consolidation of sand columns, repair of limestone monuments, and to some extent for remediation of cracks in concrete [19].

\subsection{Microbiologically induced calcite precipitation (MICP)}

Microbiologically induced calcite precipitation (MICP) is the process by which microorganisms deposit carbonates as part of their basic metabolic activities [20]. Precipitation of calcium carbonate crystals occurs by heterogeneous nucleation on the bacterial cell wall. Once super saturation is achieved and these crystals precipitate inside the pore spaces. The bacteria not only initiate calcite precipitation, but also serve as nucleation sites for calcite crystals in association with other factors such as $\mathrm{Ca} 2+$ ions, dissolved inorganic carbon, $\mathrm{pH}$, and temperature in the medium [20]. These carbonates/ calcite crystals act as cloggers in the building materials by filling the voids and thereby reducing permeability [21].

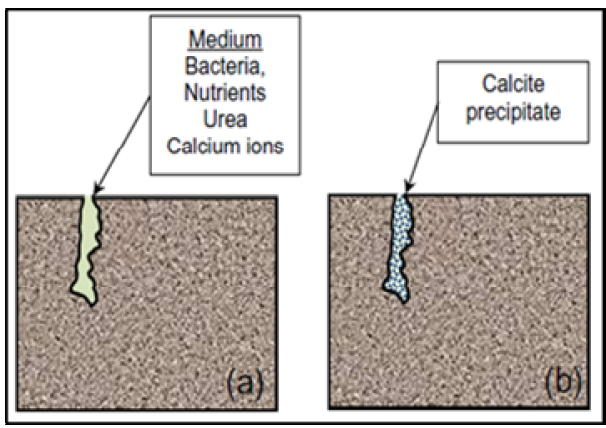

Figure 1. Process of MICP: (a) surface pore filled with medium; (b) calcite precipitates and seals the pore [21].

\subsection{Previous research on the use of bacteria}

Many research already been done in order to improve the durability and Table 1 provide summary on previous research which more focusing in improving the durability and water absorption level of bricks or concrete.

According to the remark from Table 1, its can be concluded that using bacteria toward brick or concrete can help to improve the water absorption level and increase their durability. Therefore it is possible to solve the ICEB problem by introducing the used of bacteria. Continuous research on the effect of bacteria should be done in future by introducing the used of bacteria toward ICEB.

\section{Conclusion}

Various methods and bacteria have been used by researchers in order to obtain the best solution on the effect of bacteria toward concrete and bricks as well as to achieve environmentally and sustainable solution. Although there are many researchers do not use the same type of bacteria in their research but the results obtained were very positive and very assuring. Therefore, it can be conclude that by using the bacteria, it can help to improve the durability of concrete or bricks properties. Meaning that, all the bacteria used by the previous researcher manage to undergo MICP process to produce calcite 
precipitation. Then the calcite will act as protective film coating on the surface of concrete or bricks which prevented ingress of water by filled all the pore with calcite. As the large amount of pores is plugged due to precipitation, the pore connectivity and porosity will be decreased. Hence it will reduce the rate of water absorption in concrete or bricks. Thus the durability problem is fully solved.

Table 1. Various researches works on bacteria.

\begin{tabular}{|c|c|c|c|}
\hline Researcher & $\begin{array}{c}\text { Type of } \\
\text { bacteria }\end{array}$ & Findings & Remark \\
\hline $\begin{array}{l}\text { Shahrood et al, } 2015 \\
\text { "Surface treatment of } \\
\text { concrete bricks using } \\
\text { calcium carbonate } \\
\text { Precipitation" }[22]\end{array}$ & $\begin{array}{l}\text {-Dimethyl } \\
\text { carbonate } \\
\text { (DMC) }\end{array}$ & $\begin{array}{l}\text {-water absorption } \\
\text {-compressive } \\
\text { strength }\end{array}$ & $\begin{array}{l}\text {-the water absorption of concrete } \\
\text { bricks significantly reduce and } \\
\text { the compressive strength } \\
\text { significantly increase. }\end{array}$ \\
\hline $\begin{array}{c}\text { D. Bernardi et al, } 2014 \\
\text { "Bio-Bricks: Biologically } \\
\text { cemented sandstone } \\
\text { bricks"'[23] }\end{array}$ & $\begin{array}{l}\text {-Sporosarcina } \\
\text { paseurii }\end{array}$ & $\begin{array}{l}\text {-void ratio and dry } \\
\text { density } \\
\text {-compressive } \\
\text { strength }\end{array}$ & $\begin{array}{l}\text {-the void ratio with MICP } \\
\text { treatment shows decreasing in } \\
\text { results compared to control } \\
\text { specimen. }\end{array}$ \\
\hline $\begin{array}{c}\text { Abhjit et al, } 2013 \\
\text { “Bacterial Calcification } \\
\text { for Enhancing } \\
\text { Performance of Low } \\
\text { Embodied Energy Soil- } \\
\text { Cement Bricks", } 24]\end{array}$ & $\begin{array}{l}\text { - Bacillus } \\
\text { megaterium }\end{array}$ & $\begin{array}{l}\text {-water absorption } \\
\text { test } \\
\text {-wet compressive } \\
\text { strength } \\
\text {-porosimetry } \\
\text { analysis }\end{array}$ & $\begin{array}{l}\text {-the calcite crystal act as } \\
\text { biosealant by filling the pores } \\
\text { which leads to reduction in water } \\
\text { absorption, porosity, permeability } \\
\text { and enhance the strength of the } \\
\text { bricks. }\end{array}$ \\
\hline $\begin{array}{l}\text { Navdeep et al, } 2012 \\
\text { "Improvement in strength } \\
\text { properties of ash bricks } \\
\text { by bacterial calcite"[21] }\end{array}$ & $\begin{array}{l}\text {-Bacillus } \\
\text { megaterium }\end{array}$ & $\begin{array}{l}\text {-microbiological } \\
\text { sand plugging } \\
\text {-water absorption } \\
\text { and initial rate of } \\
\text { water absorption } \\
\text {-compressive } \\
\text { strength } \\
\end{array}$ & $\begin{array}{l}\text {-the bacteria used was found to be } \\
\text { very effective in calcite } \\
\text { deposition on the surface of } \\
\text { bricks which lead to reduction in } \\
\text { permeability, decrease in water } \\
\text { absorption leading to enhanced its } \\
\text { durability. }\end{array}$ \\
\hline $\begin{array}{l}\text { Willem et al, } 2008 \\
\text { "Bacterial carbonate } \\
\text { precipitation improves } \\
\text { the durability of } \\
\text { cementitious } \\
\text { materials"[25] }\end{array}$ & -B. sphaericus & $\begin{array}{l}\text {-absorption of } \\
\text { bacteria } \\
\text {-precipitation of } \\
\text { carbonate crystal } \\
\text {-water absorption }\end{array}$ & $\begin{array}{l}\text {-there are differences between } \\
\text { mortar cubes treated with bacteria } \\
\text { and a calcium which show less } \\
\text { water absorption compared to } \\
\text { untreated specimens. }\end{array}$ \\
\hline
\end{tabular}

\section{Acknowledgment}

This study has been granted by Universiti Tun Hussien Onn Malaysia (UTHM) under GIPS Vot. U264.

\section{References}

[1] P.T. Laursen, N.A. Herskedal, D.C. Jansen and B. Qu, Interlocking compressed earth blocks walls: Out-of-plane structural response, 15th World Conference on Earthquake Engineering, Lisbon, Portugal, 71-81, (2012).

[2] S. Maini, Earthen Architecture in the World, Auroville Earth Institute, (2010). < retrieved from http://www.earth-auroville.com/> (accessed on November, 2015).

[3] K.B. Anand and K. Ramamurthy, Development and evaluation of hollow concrete interlocking block masonry system, The Masonry Society Journal, 23(1), 11-19, (2005).

[4] F.V. Riza, I.A. Rahman and A.M.A. Zaidi, A brief review of compressed stabilized earth brick (CSEB), International Conference on Science and Social Research, Kuala Lumpur, 999-1004, (2010). 
[5] P. Jaquin, How mud bricks work using unsaturated soil mechanics principles to explain the material properties of earth buildings, EWB-UK National Research Conference, United Kingdom, 49-51, (2010).

[6] G. Wilson, S.L. Barbour and D.G. Fredlund, The prediction of evaporative fluxes from unsaturated soil surfaces, Alonso and Delage (eds), France, 423-429, (1995).

[7] P. Jaquin, Analysis of historic rammed earth construction, PhD Thesis, University of Durham, United Kingdom, (2008).

[8] J.E. Oti, J.M. Kinuthia and J. Bai, Engineering properties of unfired clay masonry bricks, Journal of Engineering Geology, 107(3-4), 130-139, (2009).

[9] P.J. Walker, Strength and erosion characteristics of earth blocks and earth block masonry, Journal of Materials in Civil Engineering, 16(5), 497-506, (2004).

[10]A. Guettala, A. Abibsi and H. Houari, Durability study of stabilized earth concrete under both laboratory and climatic conditions exposure, Journal of Construction and Building Materials, 20(3), 119-127, (2006).

[11]E.A. Adam and A.R.A. Agib, Compressed stabilised earth block manufacture in Sudan, Graphoprint for the United Nations Educational, Scientific and Cultural Organization, France, Paris, (2001).

[12]D.E. Gooding and T.H. Thomas, The potential of cement-stabilised building blocks as an urban building material in developing countries, Overseas Development Administration, United Kingdom, (1995).

[13]L. Keefe, Earth Building: Methods and Materials, Repair and Conservation, Taylor and Francis, New York, 145-156, (2005).

[14]R. Siddique and N.K. Chahal, Effect of ureolytic bacteria on concrete properties, Journal of Construction and Building Materials, 25(10), 3791-3801, (2011).

[15]H.S. Chafetz and C. Buczynski, Bacterially induced lithification of microbial mats, Journal of Palaios, 7, 277-293, (1992).

[16]H. Knorre and K.E. Krumbein, Bacterial Calcification, Book of Microbial Sediments, Springer, Berlin, 25-31, (2000).

[17]F. Hammes, N. Boon, J. de Villiers, W. Verstraete and S.D. Siciliano, Strain-specific ureolytic microbial calcium carbonate precipitation, Applied and Environmental Microbiology, 69, 49014909, (2003).

[18] M.P. Harkes, L.A Van Paassen, J.L. Booster, V.S. Whiffin and M.C.M. Van Loosdrecht, Fixation and distribution of bacterial activity in sand to induce carbonate precipitation for ground reinforcement, Journal of Ecological Engineering, 36(2), 112-117, (2010).

[19] W. De Muynck, N. De Belie and W. Verstraete, Microbial carbonate precipitation in construction materials: A review, Journal of Ecological Engineering, 36(2), 118-136, (2010).

[20] S. Stocks-Fischer, J.K. Galinat and S.S. Bang, Microbiological precipitation of $\mathrm{CaCO}_{3}$, Journal of Soil Biology and Biochemistry, 31(11), 1563-1571, (1999).

[21]N.K. Dhami, M.S. Reddy and A. Mukherjee, Improvement in strength properties of ash bricks by bacterial calcite, Journal of Ecological Engineering, 39, 31-35, (2012).

[22] S. Amidi and J. Wang, Surface treatment of concrete bricks using calcium carbonate, Journal of Construction and Building Materials, 80, 273-278, (2015).

[23]D. Bernadi, J.T. Dejong, B.M. Montoya and B.C. Mattinez, Bio-bricks: Biologically cemented sandstone bricks, Journal of Construction and Building Material, 55, 462-469, (2014).

[24]A. Mukherjee, N.K. Dhami, B.V.V Reddy and M.S. Reddey, Bacterial calcification for enhancing performance of low embodied energy soil-cement bricks, Third International Conference on Sustainable Construction Materials and Technology, Kyoto, (2013).

[25]W. De Muynck, D. Debrouwer, N. De Belie and W. Verstraete, Bacterial carbonate precipitation improves the durability of cementitious materials, Journal of Cement and Concrete Research, 38(7), 1005-1014, (2008). 